Article

\title{
Biogas Micro-Production from Human Organic Waste-A Research Proposal
}

\author{
Alberto Regattieri * (iD, Marco Bortolini (D), Emilio Ferrari, Mauro Gamberi and Francesco Piana \\ Department of Industrial Engineering, Alma Mater Studiorum-University of Bologna, \\ Viale del Risorgimento 2, Bologna 40136, Italy; marco.bortolini3@unibo.it (M.B.); emilio.ferrari@unibo.it (E.F.); \\ mauro.gamberi@unibo.it (M.G.); francesco.piana2@unibo.it (F.P.) \\ * Correspondence: alberto.regattieri@unibo.it; Tel.: +39-051-2093400
}

Received: 2 December 2017; Accepted: 24 January 2018; Published: 27 January 2018

\begin{abstract}
Organic waste (OW) management tackles the problem of sanitation and hygiene in developing countries and humanitarian camps where unmanaged waste often causes severe health problems and premature death. OW still has a usable energy content, allowing biogas production, potentially contributing to satisfy the local needs, e.g., cooking, lighting and heating. Digesters are the devices converting OW into biogas under anaerobic conditions. They are simple and effective solutions for the OW management in rural areas, humanitarian camps and remote developing regions, producing energy and fertilizers for local farming as residual. This paper describes the design and lab-test of a domestic OW management system integrating a waterless toilet with a small-scale digester producing safe biogas for local micro-consumption. Starting from people's needs and an extensive review of the current state-of-art technology, the proposed system's key innovation and strength is the combination of effectiveness and a very simple construction, set up and use, fitting with the rural conditions and raw materials available within the emerging countries. A small-scale prototype is assembled and lab-tested assessing the quantity-i.e., productivity-and quality-i.e., composition and methane content-of the produced biogas. The measured productivity in terms of specific biogas production (SBP) is of about $0.15 \mathrm{~m}^{3} / \mathrm{kg}_{\mathrm{SV}}$ and a methane content of about $74 \%$ in mass match the energy needs of domestic users, encouraging the spread of such systems in developing regions and rural areas.
\end{abstract}

Keywords: organic waste management; biogas micro-production; humanitarian plant; anaerobic digestion; excreta disposal; waterless toilet

\section{Introduction}

Managing waste within developing regions and refugee camps is highly challenging. Low or null technologies together with economic and social difficulties often undermine the possibility to process waste safely, exposing people and the environment to severe risks [1]. Among the common waste streams, organic waste (OW) is critical in terms of quantity and quality issues [2-7]. It contains infectious pathogens, toxic chemicals, heavy metals and, in some cases, substances that are genotoxic or radioactive $[8,9]$. People produce excreta and urine, known as OW from human body (OWHB). Its quantity depends on the person's diet and eating habits, varying from 0.5 to $1.5 \mathrm{~kg} /$ day $[10,11]$. Together with OWHB, the municipal solid waste (MSW) includes trash and garbage from the daily life of people. MSW has a significant organic fraction [2] and a variable composition depending on the place and time of the year [12]. In addition, OW comes from breed animals, e.g., cattle, pigs, etc., in the form of animal manure (AM) $[13,14]$. Finally, agriculture and other basic anthropic activities produce OW as minor products, e.g., rice straw, pruning, olive leaf and horticultural sorting during the growing activities [2]. 
The impact and damage of OW on human hygiene and the sanitation of the living areas increases in overpopulated areas, as in the congested humanitarian camps where refugees live together in temporary unstable conditions. Such camps are set after emergencies, man-made or natural disasters, wars, earthquakes, floods and typhoons [15]. In recent decades, the number of such camps is growing significantly due to the increasing number of humanitarian crises [16]. The first response of the international community to the increased scale of refugee movements is humanitarian assistance, usually provided within refugee camps [17,18].

Humanitarian camps and the emergency areas are often full of debris and a mix of disparate materials used to aid people, while masses of unmanaged OW are the result of the everyday human life without proper treatment systems [18]. Because waste and OW management affect personal hygiene, safety and health, a great deal of attention is mandatory. Sanitation and hygiene programmes, at local and global level, aim at setting a safe living environment, reducing the incidence of environment-related diseases [19].

This paper aims at contributing to OW management by presenting a simple, cheap and easy-use solution for biogas micro-production from OWHB. The system includes a waterless toilet connected to a simple bio digester for biogas micro-production under anaerobic conditions. Biogas is an important and renewable source of household energy. In parallel, the residual solid matter is a good fertilizer for agriculture. Such solution not only tackles the issue of unmanaged OW by neutralising its health risks and diseases but creates a secondary resource of positive impact for the daily life of people and refugees. This win-win approach is rare but strongly encouraged by scientists and humanitarian organisations representing an innovative pattern in this field.

According to this topic and goal, the reminder of the paper is organised as follows. Section 2 revises the introduced topic. Section 3 focuses on the key biogas features and bio digesters for local use, while Section 4 describes the proposed system and prototype. Section 5 is about the lab-test results, while the conclusions and the future research opportunities are in Section 6.

\section{Waste Management and Sanitation in Developing Regions and Humanitarian Camps}

Life in developing regions and humanitarian camps is often in non-permanent living solutions where vital and life-saving assistance is offered at borderline standards [20]. While the basic needs are similar in most of the contexts, the living conditions vary across areas depending on a complex interaction of social, economic, political and attitudinal factors. Construction materials, camp layout, services and infrastructures should fit to these environmental factors [21]. Even if the existing literature provides multiple guidelines to follow, during the early stages of the camp settlement, in extreme emergency contexts, in presence of urgency, poverty and insecurity, little time, few resources and raw tools are available for the camp set up and everyday life [17,19,20,22,23]. Within emergencies and without modern and advanced systems, the collection and proper disposal of waste is among the most important, and often neglected, problems to face. Typically, the emphasis is on the raw removal of waste from the areas where people live, to avoid potential health and safety problems. After that, an integrated, intelligent and planned approach for the waste management is necessary [24]. Elements of attention, recommendations and risks while tackling this issue are suggested by the literature and the current practice $[25,26]$. Among them, OW treatment is crucial, because of the nature of OW and environmental, social and safety reasons [27].

In recent decades, the term sanitation is used to refer to the environmental conditions affecting community health $[28,29]$. It includes the means of collecting and disposing excreta and community liquid waste in hygienic manners that do not undermine the health of individuals and communities [30]. A reference example is faecal-oral and diarrhoea. Such communicable diseases are the major cause of mortality and morbidity in emergencies, where hygienic behaviours influence their transmission [31]. The United Nations reports that diarrhoea kills approximately 2.2 million people every year and most of the affected individuals are children under five years of age [32]. Diarrhoea is the second largest killer of children under five in the world [33]. Agencies and providers working at local, 
national and international levels are increasing their efforts in preventing and controlling the major communicable diseases and health problems by promoting large-scale and easy actions to create barriers to the infection spread. In particular, they focus on the appropriate use and maintenance of sanitation facilities to prevent open defecation and burying of faeces, the safe disposal of faeces and the improvement of personal hygiene [33]. For example, thorough and frequent hand washing ensures that faecal contamination on hands is not transmitted via food or water (Figure 1). Washing hands with soap reduces the risk of diarrhoea by $42 \%$ to $47 \%$ [34]. Keeping waterways and water sources clean is dependent on how the waste is managed. If people use inadequate latrines, such as pit latrine basic toilets that collect faces in a hole in the ground, or they defecate in the open, human waste seeps into groundwater, wells, rivers and the sea, causing environmental problems due to bacterial contamination [22].

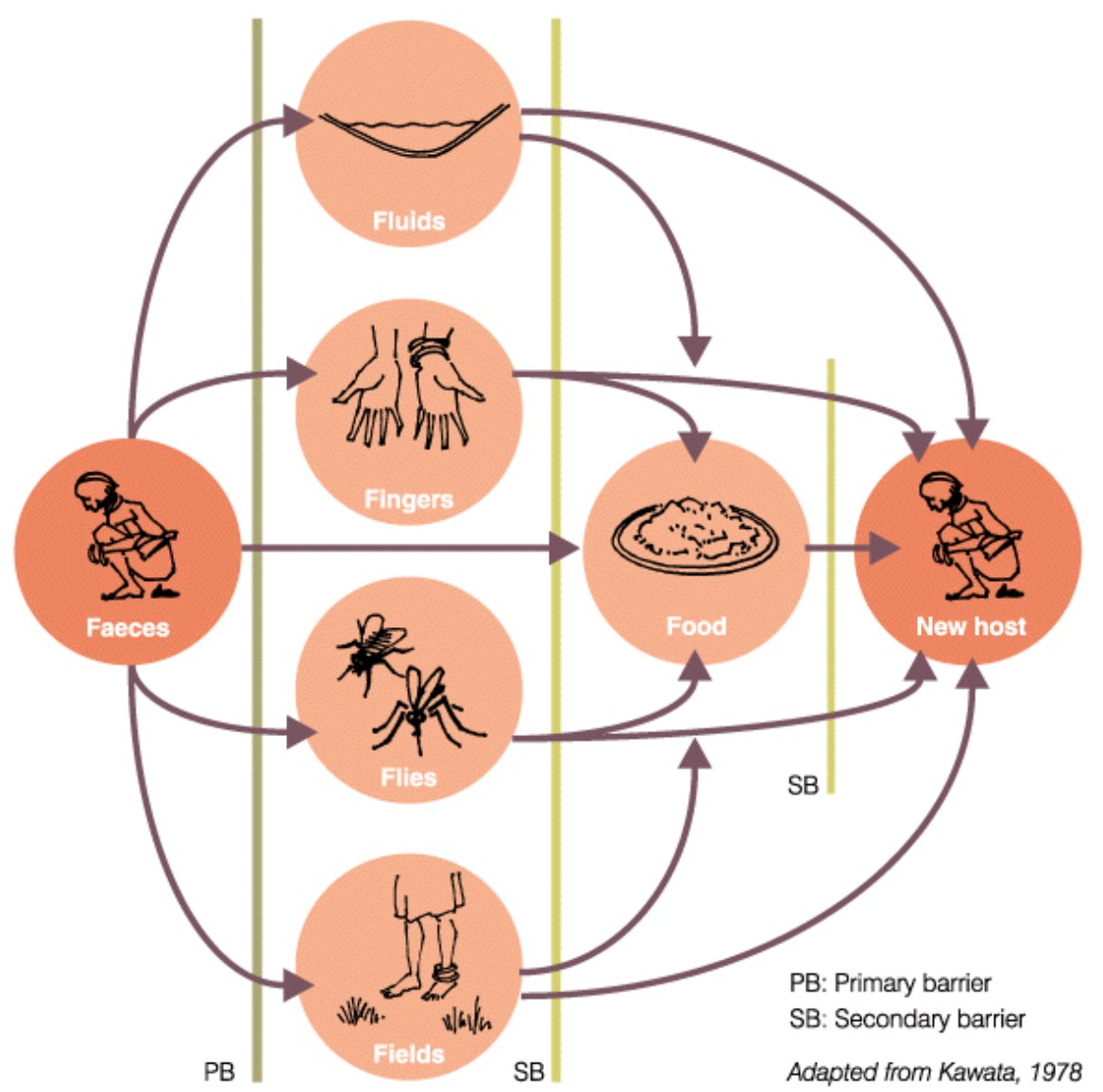

Figure 1. Faecal-oral transmission routes [32].

OWHB is a threat to human health. The importance of having adequate disposal systems is well documented but rarely applied. In refugee camps, over $30 \%$ of the inhabitants do not have adequate waste disposal services and access to latrines [19,35]. This is mainly because, during the early stages of the camp design and planning, little attention is paid to effective OWHB disposal systems [16]. In addition, approximately 2.4 billion people in rural and urban areas do not have access to adequate sanitation services [36]. In such contexts, the natural behaviour of the population is to try to continue using their traditional defecation practises, wherever possible. Otherwise, people adopt 'coping mechanisms', resulting in inadequate and unsafe practises both for them and the surrounding environment [24].

The aim of safe excreta disposal systems is to provide and maintain the environment free from contamination risks [37]. The literature and the humanitarian organisation manuals propose a wide range of conventional sanitation systems, ranging from septic tanks to bucket latrines, discussing their 
strengths and weaknesses [33,38-40]. The acceptance factors to consider are coverage, space limitation, modularity, maintenance, socio-cultural acceptance and economic sustainability [41]. Among the most relevant issues to face are the effects on dignity and protection, especially for women, children, elderly and disabled individuals [42]. Additionally, night-time use of the traditional latrines is found to be limited due to a perception of insecurity, lack of lighting, distance from tents and other unsafe conditions, particularly for woman and children [20]. In conclusion, open defecation and raw-pit latrines remain major problems to face after a catastrophe and they are significant problems in wide areas of developing countries [32]. Furthermore, most of the existing sanitation systems do not avoid environment contamination. The OW remains within the environment after collection without losing its polluting power. In this way, organic materials are not eliminated and they represent a steady threat for human and the environmental safety with serious economic and welfare consequences.

To tackle such problems, both technological solutions and best practices need to be spread, e.g., design, appropriate use and maintenance of sanitation facilities, safe disposal of faeces, personal hygiene practises, access to clean water and storage water facilities, etc. Matching the introduced needs and best practises, an effective way to tackle OWHB management deals with the anaerobic digestion of faeces and urine to micro-produce biogas, for local use, and fertilizers, as residual, for local agriculture [11]. Biogas digesters could be an effective solution to face the sanitation problems without restricting or forcing way-of-living changes and, in parallel, avoiding the illegal market of fossil fuels. The following Section 3 presents a review of fundamentals about anaerobic digestion of OWHB and discusses the new idea to integrate a waterless safe toilet system to a biogas micro-production digester.

\section{Anaerobic Digestion Review}

Anaerobic digestion is the biological process to convert organic matter into a methane rich biogas $[26,43,44]$. It is a well-established technology for the treatment of the organic fraction of various waste materials $[10,11,13,45-48]$. Well documented attempts to use anaerobic digestion on OWHB date from the mid-nineteenth century, when digesters were constructed in New Zealand and India. In 1890, a sewage sludge digester built in Exeter, UK, fuelled the local street lamps [44]. The spread of biogas technology was in the 1970s, when high oil prices motivates research into alternative energy sources. In these years, rapid growth of biogas use took place in several Asian, Latin American and African countries [49,50].

Because it is recognised among the most energy-efficient and environmentally friendly technologies for bioenergy production [51-55], anaerobic digestion of OWHB can mitigate the environmental and human health problems [56] while representing, at the same time, an effective solution for managing such a waste. This is particularly true within developing countries due to the lack of other OWHB collection and treatment systems [43,46,47,56-59].

Anaerobic digestion occurs to the organic biodegradable matter in airproof reactor tanks, commonly named digesters, and it generates two main products, i.e., biogas and nutritious digestate [60], containing nitrogen, phosphorous and potassium [61]. Furthermore, anaerobic treatment minimises the survival of pathogens within OWHB, which is important for using the digested residue as fertiliser with no safety hazard [51]. Finally, biogas drastically reduces air-pollutant-emissions compared to fossil fuels $[43,51,62,63]$.

\subsection{Anaerobic Digester Structure and Layout}

The structural composition of an OWHB digester includes, as the main component, a vessel or tank that contains the slurry. Such a tank should be hermetic and watertight to create anaerobic conditions. No strong limitations are present on the construction materials, its shape and size $[56,63,64]$. It must include a method of filling the slurry as well as a way of extracting the biogas. Multiple basic configurations and hybrid combinations are available, e.g., one-stage vs. two-stage industrial bio digester, dry vs. wet, batch vs. continuous, etc. [65]. Within developing regions, bio digesters are not novel solutions and show benefits on the basic livelihood indicators as well as rural economic 
development [66]. Lansing [67] presents the potential of biogas production from a bio digester, showing its impact on sanitation and decrease in illnesses. Government policies promote the use of household bio digesters to tackle the problem of OWHB management $[58,61,63]$. These bio digesters are simpler than industrial solutions and, commonly, they are called domestic bio digesters [44,56,68]. Domestic bio digesters are smaller than industrial bio digesters [44,56,57]; they are both onsite-constructed or prefabricated [57] with different materials, as brick, concrete, and plastics. Nowadays, their diffusion is wide, and governments and institutions are involved in subsidy schemes, planning, design, construction, operation and maintenance of such systems [44]. Several countries in Asia and Africa, including China, India, Nepal, Bangladesh, Cambodia, Vietnam, Kenya, Rwanda and Tanzania, are launching massive campaigns to promote biogas technology [62].

Figure 2 shows three major types of domestic bio digesters commonly used in the developing countries $[44,45,52,57,63,69-74]$, i.e., the plug flow digester, sausage-bag or tubular/plastic digester, the fixed-dome digester or Chinese digester and the floating drum digester, also called telescopic digester or Hindu digester. Even if the gas collection method and design are different, the digestion process is the same. They are designed for use with OWHB and AM [75].

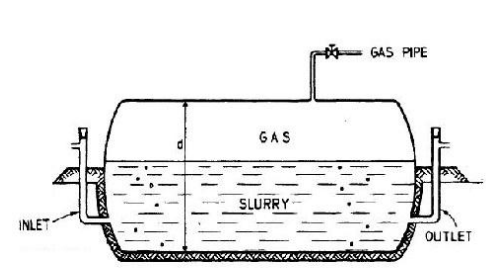

(a)

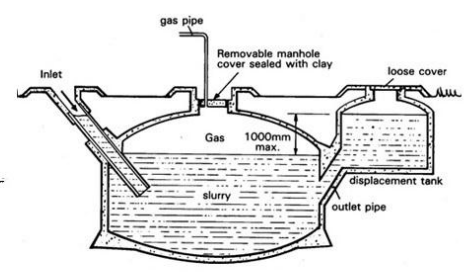

(b)

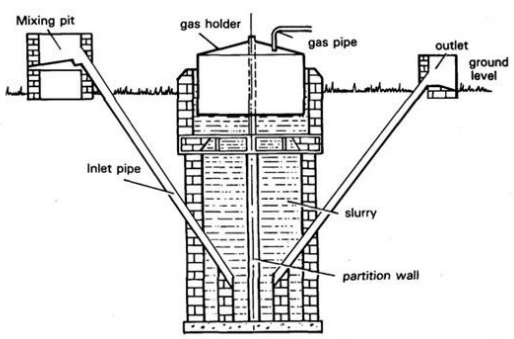

(c)

Figure 2. Bio digester configurations: (a) plug flow digester [73]; (b) fixed-dome digester [74]; (c) floating drum digester [74].

The plug flow digester is a polyethylene tank. At its extremities, there are the slurry inlet and outlet, while on top there is the biogas outlet pipe. This digester is made of a single tank, easing transportation, even if its lifetime is often relatively short [53,57]. It is common in the developing regions for its simplicity. Lansing et al., develop interesting experiments in Haiti $[67,76]$. On the contrary, the fixed-dome digester is a non-movable, two-tank system. The slurry is generally stored in an underground vessel, protecting it from physical damage and saving space, while the produced biogas is piped to a separate chamber $[60,77,78]$. Globally, the fixed-dome digester is a local autonomous plant, quite compact but with relevant repairing costs in the case of leakage $[57,75,79]$. Finally, the floating drum digester is an underground digester with a moving gas holder. Biogas is collected in the top gas drum moving up and down according to the amount of the produced gas [77]. The level of productivity is visible, immediately, but the moving drum may cause maintenance and gas-leakage problems [57]. Despite their diffusion, a common limit of such three solutions is in the building and management complexity, requiring high-value materials, human skills and economic initial investments. Furthermore, due to their dimensions, such solutions are not dedicated to single users, as families, but belong to common public facilities. For this reason, acceptance difficulties are probable. To overcome these weaknesses the proposed micro-scale domestic digester, assembled from simple raw and recycled materials, becomes of interest next to these larger scale solutions.

\subsection{OW Biogas Properties}

The composition of biogas varies according to the type of feedstock and operating conditions of the digester [56]. The standard composition of biogas, coming from methanogenic bacteria working in anaerobic conditions, is shown in Table 1 [80]. The most common use of biogas within developing countries, from small-scale digesters, is for cooking and lighting, known as two basic needs for 
everyday life of poor people [81]. Each ton of OW (dry weight) produces $120 \mathrm{~m}^{3}$ of biogas in industrial digesters [82] with a heating value of about 21-24 MJ $/ \mathrm{m}^{3}$ [44]. It follows that $1 \mathrm{~m}^{3}$ of biogas allows for cooking up to three meals for a family of five to six people or to operate a $60-100 \mathrm{~W}$ bulb for six hours [75]. Depending upon the design and operating conditions, the efficiency of biogas cook stoves in developing countries ranges from $20 \%$ to $56 \%[82,83]$.

Table 1. Standard composition of biogas produced through anaerobic digestion [80].

\begin{tabular}{ccc}
\hline Compound & Symbol & Mass Percentage [\%] \\
\hline Methane & $\mathrm{CH}_{4}$ & $50-70$ \\
Carbon Dioxide & $\mathrm{CO}_{2}$ & $30-40$ \\
Hydrogen & $\mathrm{H}_{2}$ & $5-10$ \\
Nitrogen & $\mathrm{N}_{2}$ & $1-2$ \\
Water Vapour & $\mathrm{H}_{2} \mathrm{O}$ & 0.3 \\
Hydrogen Sulphide & $\mathrm{H}_{2} \mathrm{~S}$ & traces \\
\hline
\end{tabular}

\section{Proposed Biogas-Micro-Production Integrated System}

This study aims to provide a domestic waterless toilet integrating an anaerobic biogas digester using basic and immediately available materials. The target is humanitarian camps and poor regions so that simplicity in the system assembly, easy-use, low cost and no maintenance need are of primary importance even if this generates some performance decrease [81]. In addition, the reuse of existing devices, e.g., tanks, and the recycle of materials, e.g., packaging, pipes, etc. is privileged. Globally, the system follows the general win-win strategy outlined in Section 1, simultaneously facing a sanitation issue through OWHB management while producing a useful secondary energy resource $[13,67]$.

Starting from the configurations of Figure 2, the two-tank pattern is chosen, as in the fixed-dome digester, because it is simpler to build and more reliable than the other types. Two linked vessels are for OWHB digestion and the biogas collection and storage. Differently from the fixed-dome digester that uses masonry structures, cheaper and easy-moving tanks and jerry cans are used. They are typical relief items, common and immediately available devices within developing countries and humanitarian camps. The United Nations Humanitarian Response Depot (UNHRD) ships tanks of multiple shapes and capacities, e.g., from 5 to 200 litres, with humanitarian aid in almost all emergency response projects. Such tanks are collapsible and they have the same standard screwed top (diameter of $120 \mathrm{~mm}$ ). Figure 3 presents the overview of the proposed anaerobic digester waterless toilet.

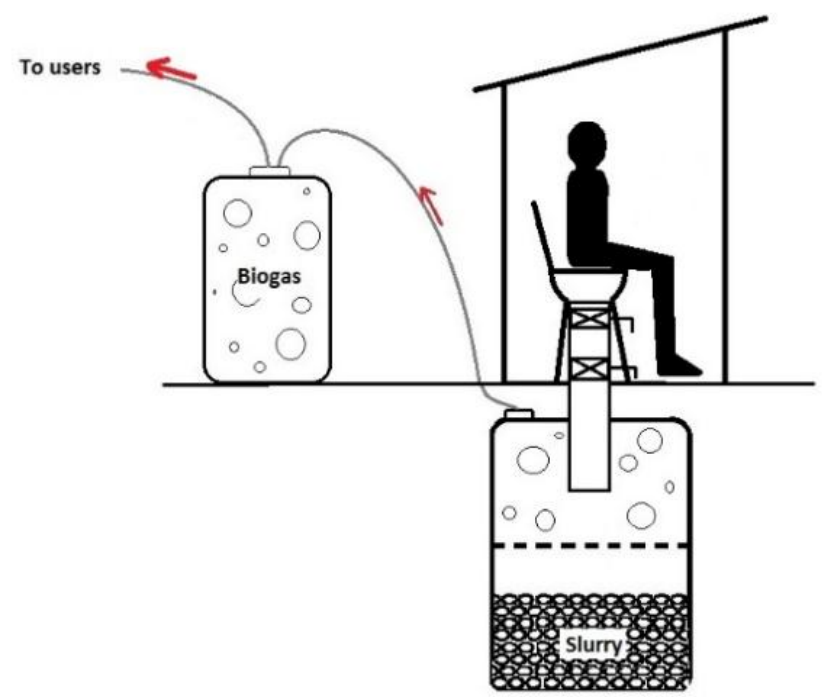

Figure 3. Overview of the proposed anaerobic digester toilet for developing regions and humanitarian camps. 
The slurry tank is directly connected to the toilet and a separate vessel collects the produced biogas. The top opening is a critical part of the device, preventing biogas overflow and losses during waste refilling. In practice, multiple alternatives match these needs, such as automatic non-return valves. Frequently, their cost is too high for the study target so that, in this context, a pipe assembled with a series of two common plastic global valves is used (Figure 4). This mechanism permits to fill the digester during the day by opening and closing the valves in sequence without losing biogas and minimising the introduction of oxygen within the anaerobic chamber. It further prevents bad smells and it is compatible to the double digester installation of Figure 3. Finally, the training required for users to make them able to feed the system without gas losses is very low, safe and possible without advanced skills.
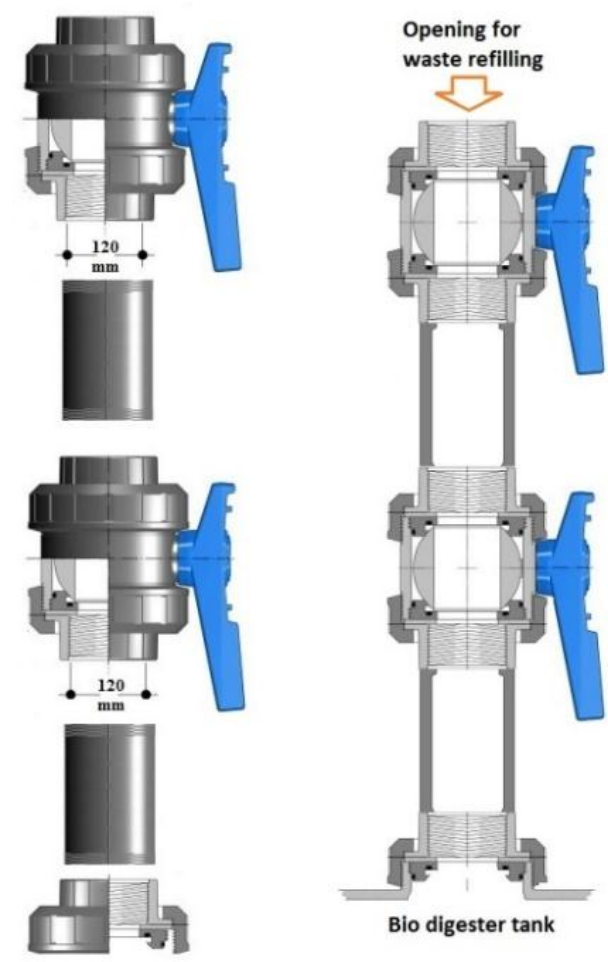

Figure 4. Digester filling pipe.

The biogas collector tank is made from a common jerry or a plastic bag for liquids, while a common PVC pipe connects this tank to the digester. The tank capacity has to match the digester productivity. For example, if the target is a family of six people, a 50-litre tank could be fine. The last part of the system is the pipe connecting the biogas tank to the burner. Within the proposed solution, it is made of a simple and immediately available plastic or rubber pipe. To guarantee the system security, i.e., to prevent the flame from returning during the use of a burner, it is mandatory to insert a flame-breaker within the pipe. Finally, because the bio digester has to work under anaerobic conditions, it is recommended to use sealing paste, such as silicone or Teflon, or to use pipes and valves with a screw-end. This solution is preferable and simpler. According to such features, a preliminary prototype of the proposed domestic anaerobic digester toilet from relief items is assembled. Lab-test and experimental evidences are covered in the following section.

\section{Prototyping and Experimental Lab-Test}

A small-scale digester prototype allows testing the proposed solution, the biogas productivity and quality. Figure 5 presents a picture and the schematic of the prototype equipped with sensors. 
The digester (the blue jerry can of Figure 5) is 6.9 litres, while the biogas vessel (the white vessel of Figure 5) is of 5 litres. During the experiment, a 0.6-litre biogas vessel is used, further, to increase the measurement accuracy. Pipes for biogas flow are $6 \mathrm{~mm}$ diameter pneumatic pipes, $800 \mathrm{~mm}$ long, equipped with pneumatic connection valves. Data collection is through a customised real-time interface developed in LabviewTM Integrated Development Environment (IDE). To maintain the temperature and relative humidity within controlled ranges, a climate-room chamber is used as the test environment. The air set point is of $35^{\circ} \mathrm{C}$ and the relative humidity is $25 \%$ according to typical features of common developing countries. The trends of the temperature inside the digester and of the pressure inside the biogas vessel are tracked (sampling frequency of $0.1 \mathrm{~Hz}$ ) through a Pt-100 (accuracy $\pm 0.3 \%$ ) and a $0-10$ bar membrane pressure sensor (accuracy $\pm 0.5 \%$ ).

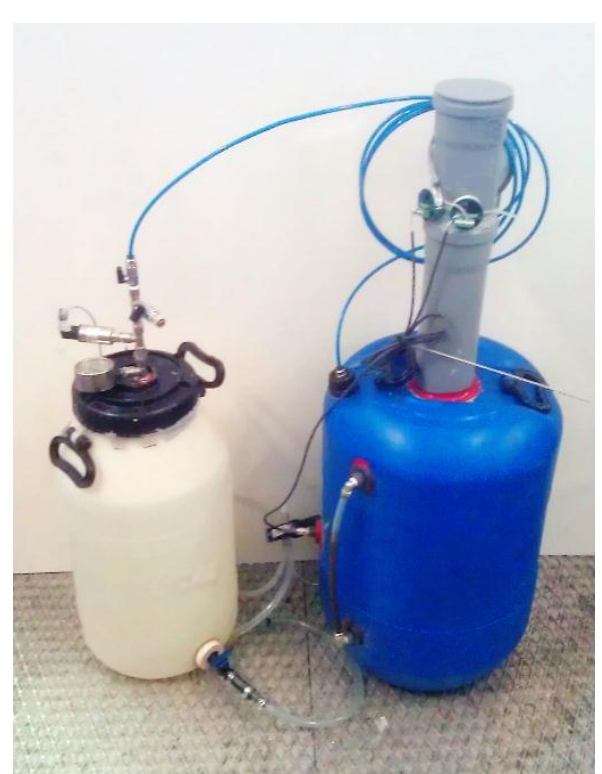

(a)

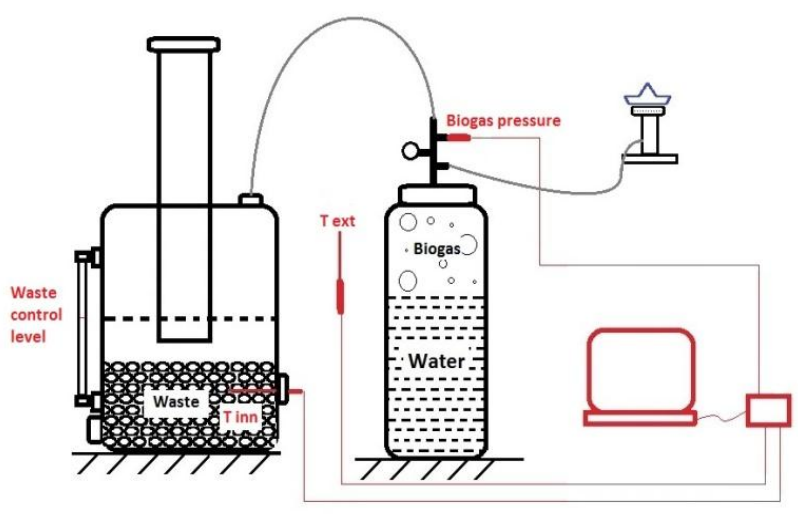

(b)

Figure 5. Domestic anaerobic digester small-scale prototype, picture (a) and schematic (b).

\subsection{Characterisation of Bio Digester and OWHB}

To study the proposed bio digester and its working conditions, a set of controlled lab-tests are done [84]. The OWHB is a mix of human faeces, urine and water. The mix composition follows the results of Haque and Haque [85] and it includes $3 \mathrm{~kg}$ of human faeces, $1.9 \mathrm{~kg}$ of urine and $0.9 \mathrm{~kg}$ of raw water, simulating the one-day living conditions of a five-person family. Such a substrate is crushed mechanically to ensure homogeneity. The standard methods suggested by the American Health Public Society [86] are applied to different samples. Values for the total solid (TS), volatile solid (VS), pH and the chemical oxygen demand (COD) are shown in Table 2.

Table 2. Organic waste from human body (OWHB) average characteristics.

\begin{tabular}{cc}
\hline Parameter & Average Value \\
\hline$\% \mathrm{TS}$ & 17.28 \\
$\% \mathrm{VS} / \mathrm{TS}$ & 73.85 \\
$\mathrm{COD}(\mathrm{mg} / \mathrm{L})$ & 40,183 \\
$\mathrm{pH}$ & 7.30 \\
\hline
\end{tabular}

Finally, the organic load rate (OLR), adapted to normal conditions according to Martì-Herrero et al. (2014) [72], is $0.417 \mathrm{~kg}_{\mathrm{SV}} / \mathrm{m}^{3} /$ day. 


\subsection{Results and Discussion}

Given the prototype of Figure 5 under the outlined test conditions and slurry composition, a preliminary one-month long test is done. Figure 6 shows the trend of the biogas pressure inside the vessel during the test together with the slurry temperature.

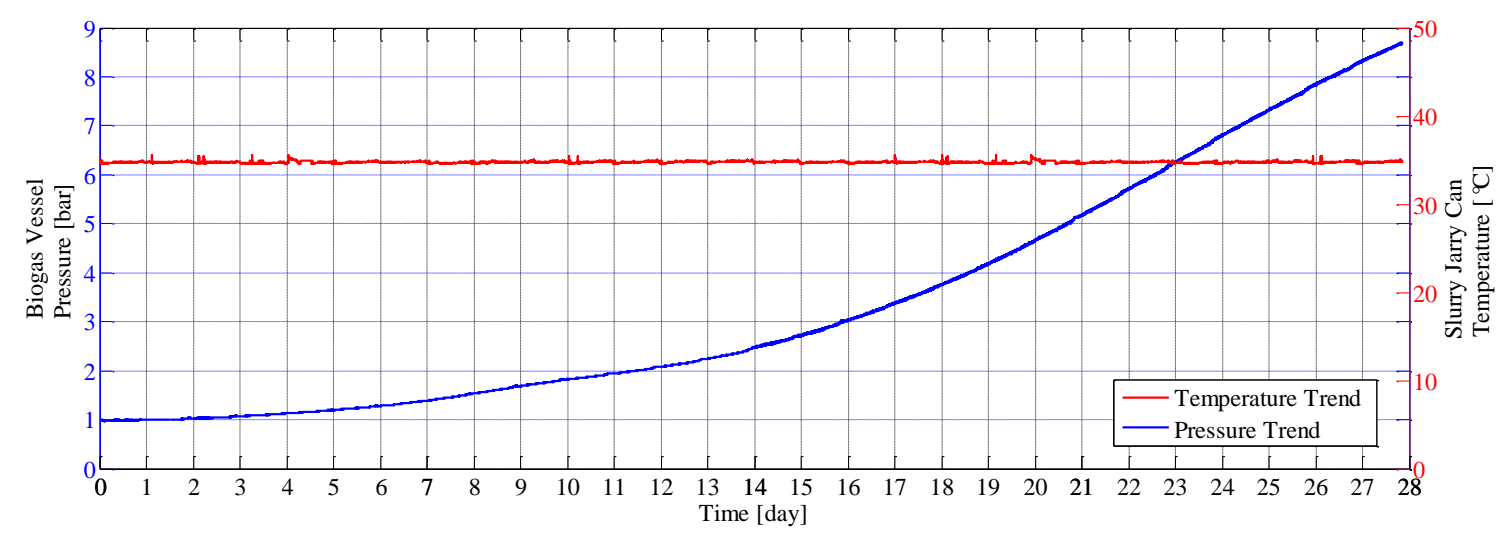

Figure 6. Trend of the biogas pressure inside the vessel during the lab test.

After a five-day little increase, the pressure rises significantly reaching a value of 8.7 bar at the end of the test. On the contrary, the slurry temperature remains approximately constant at about $34.5^{\circ} \mathrm{C}$. Starting from such data, the following Figure 7 shows the cumulative biogas production.

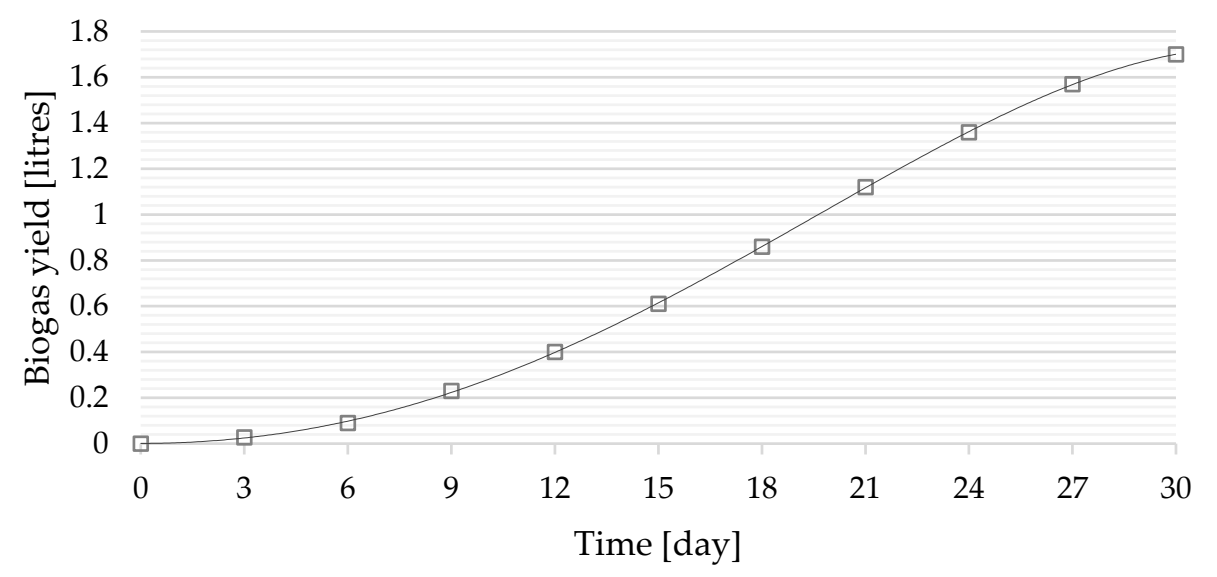

Figure 7. Trend of the biogas yield during the test.

According to Halley et al. [87], assuming the biogas as an ideal gas, the production rate comes from the ideal gas law:

$$
n=\frac{P \cdot V}{R \cdot T}
$$

where $P$ is the pressure, $V$ is the volume occupied by the biogas, i.e., the vessel volume, the pipe and the top of the slurry tank, $R$ is the universal gas constant, $T$ is the biogas temperature and $n$ is the number of produced biogas moles. Using Equation (1), it follows that $n=0.581$ mol over a one-month long test.

Globally, the so-called specific biogas production (SBP) is $0.15 \mathrm{~m}^{3} / \mathrm{kg}_{\mathrm{SV}}$ (in normal conditions). SBP deals with the efficiency of the bio digestion process in the system. Furthermore, the biogas production rate (BPR), related to the general production of biogas and equal to BPR $=O L P \cdot S B P$, is $0.07 \mathrm{~m}^{3} / \mathrm{m}^{3} /$ day, in normal conditions. These results match the recent literature. For example, Martì-Herrero et al. (2015) [84] use digesters fed by cow and pig AM and estimate SBP in the range 
$0.17-0.45 \mathrm{~m}^{3} / \mathrm{kg}_{\mathrm{SV}}$ with OLR in the range $0.18-1.15 \mathrm{~kg}_{\mathrm{SV}} / \mathrm{m}^{3} /$ day. Ferrer et al. (2011) [71], starting from an OLR in the range $0.22-0.34 \mathrm{kgSV} / \mathrm{m}^{3} /$ day, determine a BPR in the range of $0.06-0.11 \mathrm{~m}^{3} / \mathrm{m}^{3} /$ day (in normal conditions). Finally, the field-test results fit, also, with studies by Lansing et al. [76] and Alvarez and Liden [88] that start from wider ranges of OLRs and cow AM. Table 3 shows the composition of the produced biogas. The analysis adopts micro-gas chromatography Soprane ${ }^{\odot}$ software by SRA Instruments.

Table 3. Chromatographic analysis of the produced biogas.

\begin{tabular}{cc}
\hline Compound & Mass Fraction [\%] \\
\hline $\mathrm{CH}_{4}-$ Methane & 74.69 \\
$\mathrm{CO}_{2}$-Carbon dioxide & 15.30 \\
$\mathrm{H}_{2}-$ Hydrogen & 10.01 \\
Other gases & traces \\
\hline
\end{tabular}

The overall quality of the produced biogas is almost acceptable. The $\mathrm{CH}_{4}$ yield is of about $74 \%$. This value is higher than the average trend discussed in literature despite the existence of previous studies presenting similar results [14,89]. Furthermore, in the present context, the influence of the optimal mix of manure, the small scale of the system, the fully controlled anaerobic digestion environment and a potential high buffering capacity of hydro-carbonate or ammonium carbonate set favourable conditions.

Globally, from the operative viewpoint, the proposed system allows satisfying the cooking needs of families of three to four members. Furthermore, given the average level of OWHB produced by people per day [90], the proposed system is autonomous in terms of OWHB feeding vs. biogas generation. Nevertheless, AM is often available in rural contexts as additional OW.

Finally, considering the structure of the proposed digester and the mix of the typical relief items normally supplied during crisis, the proposed concept is scalable to bigger volumes.

\section{Conclusions and Future Research Opportunities}

People living in developing countries and humanitarian camps do not have standardised waste management systems and often neglect the negative effect of uncontrolled organic waste $(\mathrm{OW})$ on their health and on the environment. OW from human body (OWHB) is a significant problem and creates severe risks for people's lives. If buried, it becomes a serious problem causing water pollution, bad odours and the diffusion of flies, insects and worms. Furthermore, polluted aquifers carry lethal diseases, such as chronic diarrhoea, killing approximately 2.2 million people per year.

This paper addresses the waste and OW management and sanitation topics for developing countries and within humanitarian camps. It presents a domestic anaerobic bio digester toilet for OWHB management and valorisation to obtain biogas and solid fertilizer as residual. The system is a win-win solution to both safely dispose OWHB and to produce fuel and heat for local domestic uses. The addressed target are rural destinations with no access to advanced materials and technologies and lot of waste and OW to manage so that very simple and durable materials, normally supplied as relief items or recycled materials, are used. The assembly and preliminary lab-tests on a prototype of the bio digester assess the overall effectiveness of the idea and the chosen layout. The key results show a specific biogas production (SBP) of about $0.15 \mathrm{~m}^{3} / \mathrm{kg}_{\mathrm{SV}}$ (in normal conditions) with an organic load rate (OLR) of about $0.417 \mathrm{~kg}$ SV $/ \mathrm{m}^{3} /$ day. The mass fraction of methane within the biogas mix is of about $74 \%$. Such results are from a first full lab-test and require refinements and further validation, e.g., longer digestion time, slurry composition variations, environmental condition changes, and different tanks. Nevertheless, they are promising for the development of domestic micro-generation of biogas through OWHB anaerobic digestion within emerging and humanitarian contexts using relief and recycled items. Future research has to include such refinements before moving to the field to investigate the system's social acceptance and potential for people living together under emergencies. 
Within such a context, standardisation of the system layout and the definition of operative guidelines to maximise the quality and quantity of the produced biogas are expected.

Acknowledgments: The Authors express a deep sense of gratitude to the United Nation Humanitarian Response Depot (UNHRD)-World Food Program (WFP) of Brindisi, Italy for their support and valuable information during the development of this research.

Author Contributions: Emilio Ferrari and Francesco Piana revised the literature; Mauro Gamberi and Francesco Piana conceived and prototyped the biogas micro-production system; Marco Bortolini, Francesco Piana and Alberto Regattieri performed the lab-test and collected the results; Alberto Regattieri analysed the results; Marco Bortolini and Francesco Piana wrote the paper.

Conflicts of Interest: The authors declare no conflict of interest.

\section{References and Notes}

1. Manga, V.E.; Forton, O.T.; Mofor, L.A.; Woodard, R. Health care waste management in Cameroon: A case study from the Southwestern Region. Resour. Conserv. Recycl. 2011, 57, 108-116. [CrossRef]

2. Gutiérrez, M.C.; Siles, J.A.; Diz, J.; Chica, A.F.; Martín, M.A. Modelling of composting process of different organic waste at pilot scale: Biodegradability and odor emissions. Waste Manag. 2017, 59, 48-58. [CrossRef] [PubMed]

3. Rada, E.C.; Ferrari, A.; Ragazzi, M.; Schiavon, M.; Torretta, V. PCDD/Fs environmental impact from an anaerobic digestion treatment. Prog. Ind. Ecol. 2016, 10, 83927. [CrossRef]

4. Murugesan, V.; Joshua Amarnath, D. Control of green house gas emissions by energy recovery from the organic fraction of municipal solid waste through bio methanation process. Int. J. ChemTech Res. 2015, 8, 1168-1174.

5. Gutiérrez, M.C.; Martin, M.A.; Chica, A.F. Usual variables and odour concentration to evaluate composting process and odour impact. Environ. Technol. (UK) 2014, 35, 709-718. [CrossRef] [PubMed]

6. Lleó, T.; Albacete, E.; Barrena, R.; Font, X.; Artola, A.; Sánchez, A. Home and vermicomposting as sustainable options for biowaste management. J. Clean. Prod. 2013, 47, 70-76. [CrossRef]

7. Andreottola, G.; Ragazzi, M.; Foladori, P.; Villa, R.; Langone, M.; Rada, E.C. The Unit Intregrated Approch for OFMSW Treatment. Univ. Politeh. Buchar. Sci. Bull. Ser. C 2012, 74, 19-26.

8. Alagöz, A.Z.; Kocasoy, G. Determination of the best appropriate management methods for the health-care wastes in Istanbul. Waste Manag. 2008, 28, 1227-1235. [CrossRef] [PubMed]

9. Patwary, M.A.; O'Hare, W.T.; Street, G.; Maudood Elahi, K.; Hossain, S.S.; Sarker, M.H. Quantitative assessment of medical waste generation in the capital city of Bangladesh. Waste Manag. 2009, 29, 2392-2397. [CrossRef] [PubMed]

10. Mudasar, R.; Kim, M.H. Experimental study of power generation utilizing human excreta. Energy Convers. Manag. 2017, 147, 86-99. [CrossRef]

11. Colón, J.; Forbis-Stokes, A.A.; Deshusses, M.A. Anaerobic digestion of undiluted simulant human excreta for sanitation and energy recovery in less-developed countries. Energy Sustain. Dev. 2015, 29, 57-64. [CrossRef]

12. Alibardi, L.; Cossu, R. Composition variability of the organic fraction of municipal solid waste and effects on hydrogen and methane production potentials. Waste Manag. 2015, 36, 147-155. [CrossRef] [PubMed]

13. Decrey, L.; Kohn, T. Virus inactivation in stored human urine, sludge and animal manure under typical conditions of storage or mesophilic anaerobic digestion. Environ. Sci. Water Res. Technol. 2017, 3, 492-501. [CrossRef]

14. Lansing, S.; Botero, R.B.; Martin, J.F. Waste treatment and biogas quality in small-scale agricultural digesters. Bioresour. Technol. 2008, 99, 5881-5890. [CrossRef] [PubMed]

15. Caniato, M.; Vaccari, M. How to assess solid waste management in armed conflicts? A new methodology applied to the Gaza Strip, Palestine. Waste Manag. Res. 2014, 32, 908-917. [CrossRef] [PubMed]

16. Regattieri, A.; Santarelli, G.; Piana, F.; Gamberi, M. Classification of technical requirements and the means of addressing the problem of waste management in a refugee camp. In Humanitarian Logistics and Sustainability; Klumpp, M., Sander, L., Regattieri, A., Eds.; Springer International Publishing: Cham, Switzerland, 2015; p. 200, ISBN 3319154540.

17. Bjerregard, M.; Meekings, H. Domestic and Refugee Camp Waste Management Collection and Disposal; Oxfam Technical Briefing Notes; Oxfam GB: Newcastle, UK, 2008; Volume 15, pp. 1-8. 
18. Garfi, M.; Tondelli, S.; Bonoli, A. Multi-criteria decision analysis for waste management in Saharawi refugee camps. Waste Manag. 2009, 29, 2729-2739. [CrossRef] [PubMed]

19. UNHCR. Handbook for Emergencies; United Nations High Commissioner for Refugees: Geneva, Switzerland, 2007.

20. Birkeland, N.; Forselv, G.L.; Vogel, V. Camp Management Toolkit-Norwegian Refugee Council, Oslo, Norway, 2008; ISBN 928-82-7411-185-0.

21. Attwood, J.; Carter, C.; Banes, R.; Jensen, D.; Ravier, S. Assessment of Energy, Water and Waste Reduction Options for the Proposed AMISOM HQ Camp in Mogadishu, Somalia and the Support Base in Mombasa, Kenya; UNEP/DFS/UNSOA Technical Report; Unite Nations Environment Programme: Nairobi, Kenya, 2010.

22. Harvey, P.; Baghri, S.; Reed, B. Emergency sanitation-Assessment and programme design. Water Pract. Technol. 2011, 5, 1-19. [CrossRef]

23. Anttilator, B.; Bjerregard, M.; Jonsson, L. Disaster Waste Management Guidelines, 2 ed.; UNEP/OCHA Environment Unit: Geneva, Switzerland, 2013.

24. Bjerregaard, M.; Meekings, H. Composting of Organic Materials and Recycling; Oxfam Technical Briefing Notes; Oxfam GB: Newcastle, UK, 2008; Volume 16, pp. 1-5.

25. Hungría, J.; Gutiérrez, M.C.; Siles, J.A.; Martín, M.A. Advantages and drawbacks of OFMSW and winery waste co-composting at pilot scale. J. Clean. Prod. 2017, 164, 1050-1057. [CrossRef]

26. Cabbai, V.; De Bortoli, N.; Goi, D. Pilot plant experience on anaerobic codigestion of source selected OFMSW and sewage sludge. Waste Manag. 2016, 49, 47-54. [CrossRef] [PubMed]

27. Reed, B. Technical Notes on Drinking-Water, Sanitation and Hygiene in Emergencies; World Health Organization: Geneva, Switzerland, 2013.

28. Ersel, M. Water and sanitation standards in humanitarian action. Turk. J. Emerg. Med. 2015, 15, 27-33. [CrossRef] [PubMed]

29. De Bruijn, B. The living conditions and well-being of refugees. Human Development Research Paper (HDRP) Series, 2009; Volume 25.

30. Schuler, S. Technology for Water Supply and Sanitation in Developing Countries; WHO: Geneva, Switzerland, 1987.

31. World Health Organization. M Connolly Communicable Disease Control in Emergencies: A field Manual; WHO: Geneva, Switzerland, 2005; ISBN 9241546166.

32. Harvey, P.; Bastable, A.; Bikaba, D.; Ferron, S.; Forster, T.; Hoque, E.; House, S.; Morris, L.; Smith, M.; Verheijen, L.; et al. Excreta Disposal in Emergencies: A Field Manual; Water, Engineering and Development Centre (WEDC), Loughborough University of Technology: Loughborough, UK, 2007.

33. Marshall, G.; Lewthwaite, P.; Logan, T.; Young, K.; Png, M.M.; Koto, S. A Practical Guide to Building and Maintaining Toilets in the Pacific; LIVE\&LEARN-Environmental Education: Melbourne, Australia, 2011.

34. Curtis, V.; Cairncross, S. Effect of washing hands with soap on diarrhoea risk in the community: A systematic review. Lancet Infect. Dis. 2003, 3, 275-281. [CrossRef]

35. Depoortere, E.; Brown, V. Rapid Health Assessment of Refugee or Displaced Populations; Medecins Sans Frontieres: Paris, France, 2006; ISBN 2906498645.

36. Langergraber, G.; Muellegger, E. Ecological Sanitation-A way to solve global sanitation problems? Environ. Int. 2005, 31, 433-444. [CrossRef] [PubMed]

37. Sphere Project. The Sphere Handbook: Humanitarian Charter and Minumum Standars in Disaster Response; Geneva, Switzerland, 2011; ISBN 9781908176004.

38. Morgan, P. Toilets That Make Compost-Low-Cost, Sanitary Toilets That Produce Valuable Compost for Crops in an African Context; EcoSanRes; Stockholm Environment Institute: Stockholm, Sweden, 2008; ISBN 978-1-85339-674-8.

39. Tilley, E.; Lüthi, C.; Morel, A.; Zurbrügg, C.; Schertenleib, R. Compendium of Sanitation Systems and Technologies; Eawag-aq.: Zürich, Switzerland, 2008.

40. Ashmore, J.; Bassiouni, M.; Bjerregard, M. Planning Centralised Building Waste Management Programmes in Response to Large Disaster; Shelter Centre, ProAct: Geneva, Switzerland, 2004.

41. Fenner, R.A.; Guthrie, P.M.; Piano, E. Process selection for sanitation systems and wastewater treatment in refugee camps during disaster-relief situations. Water Environ. J. 2007, 21, 252-264. [CrossRef]

42. Patel, D.; Brooks, N.; Bastable, A. Excreta disposal in emergencies: Bag and Peepoo trials with internally displaced people in Port-au-Prince. Waterlines 2011, 30, 61-77. [CrossRef]

43. Kothari, R.; Pandey, A.K.; Kumar, S.; Tyagi, V.V.; Tyagi, S.K. Different aspects of dry anaerobic digestion for bio-energy: An overview. Renew. Sustain. Energy Rev. 2014, 39, 174-195. [CrossRef] 
44. Bond, T.; Templeton, M.R. History and future of domestic biogas plants in the developing world. Energy Sustain. Dev. 2011, 15, 347-354. [CrossRef]

45. Singh, J.; Gu, S. Biomass conversion to energy in India-A critique. Renew. Sustain. Energy Rev. 2010, 14, 1367-1378. [CrossRef]

46. Cioablã, A.E.; Ionel, I.; Tri-Tordai, G. Experimental approach for biogas production from biowaste. Int. J. Energy Environ. 2011, 5, 402-409.

47. Rao, P.V.; Baral, S.S.; Dey, R.; Mutnuri, S. Biogas generation potential by anaerobic digestion for sustainable energy development in India. Renew. Sustain. Energy Rev. 2010, 14, 2086-2094. [CrossRef]

48. Owamah, H.I.; Dahunsi, S.O.; Oranusi, U.S.; Alfa, M.I. Fertilizer and sanitary quality of digestate biofertilizer from the co-digestion of food waste and human excreta. Waste Manag. 2014, 34, 747-752. [CrossRef] [PubMed]

49. Ni, J.Q.; Nyns, E.J. New concept for the evaluation of rural biogas management in developing countries. Energy Convers. Manag. 1996, 37, 1525-1534. [CrossRef]

50. Sovacool, B.; Drupady, M. Energy Access, Poverty, and Development: The Governance of Small-Scale Renewable Energy in Developing Asia; Routledge: Abingdon-on-Thames, UK, 2012; ISBN 978-140944113-7.

51. Weiland, P. Biogas production: Current state and perspectives. Appl. Microbiol. Biotechnol. 2010, 85, 849-860. [CrossRef] [PubMed]

52. Rajendran, K.; Aslanzadeh, S.; Johansson, F.; Taherzadeh, M.J. Experimental and economical evaluation of a novel biogas digester. Energy Convers. Manag. 2013, 74, 183-191. [CrossRef]

53. Buysman, E. Biogas Production in Climates with Long Cold Winters; Wageningen University: Wageningen, The Netherlands, 2008.

54. Gwavuya, S.G.; Abele, S.; Barfuss, I.; Zeller, M.; Muller, J. Household energy economics in rural Ethiopia: A cost-benefit analysis of biogas energy. Renew. Energy 2012, 48, 202-209. [CrossRef]

55. Kabir, H.; Yegbemey, R.N.; Bauer, S. Factors determinant of biogas adoption in Bangladesh. Renew. Sustain. Energy Rev. 2013, 28, 881-889. [CrossRef]

56. Surendra, K.C.; Takara, D.; Hashimoto, A.G.; Khanal, S.K. Biogas as a sustainable energy source for developing countries: Opportunities and challenges. Renew. Sustain. Energy Rev. 2014, 31, 846-859. [CrossRef]

57. Cheng, S.; Li, Z.; Mang, H.P.; Huba, E.M.; Gao, R.; Wang, X. Development and application of prefabricated biogas digesters in developing countries. Renew. Sustain. Energy Rev. 2014, 34, 387-400. [CrossRef]

58. Mengistu, M.G.; Simane, B.; Eshete, G.; Workneh, T.S. A review on biogas technology and its contributions to sustainable rural livelihood in Ethiopia. Renew. Sustain. Energy Rev. 2015, 48, 306-316. [CrossRef]

59. Guo, M.; Song, W.; Buhain, J. Bioenergy and biofuels: History, status, and perspective. Renew. Sustain. Energy Rev. 2015, 42, 712-725. [CrossRef]

60. Vögeli, Y.; Riu, C.; Gallardo, A.; Diener, S.; Zurbrügg, C. Anaerobic Digestion of Biowaste in Developing Countries, Pratical Information and Case Studies; Eawag-Sandec: Zürich, Switzerland, 2014; ISBN 9783906484587.

61. Jatinder Singh, K.; Singh Sooch, S. Comparative study of economics of different models of family size biogas plants for state of Punjab, India. Energy Convers. Manag. 2004, 45, 1329-1341. [CrossRef]

62. Kossmann, W.; Pönitz, U.; Habermehl, S.; Hoerz, T.; Krämer, P.; Klingler, B.; Kellner, C.; Wittur, T.; Klopotek, F.V.; Krieg, A.; et al. Biogas Digest; Biogas Basics: Eschborn, Germany, 1988; Volume I, pp. 1-46.

63. Rajendran, K.; Aslanzadeh, S.; Taherzadeh, M.J. Household Biogas Digesters-A Review. Energies 2012, 5, 2911-2942. [CrossRef]

64. Aggarangsi, P.; Tippayawong, N.; Moran, J.C.; Rerkkriangkrai, P. Overview of livestock biogas technology development and implementation in Thailand. Energy Sustain. Dev. 2013, 17, 371-377. [CrossRef]

65. Nizami, A.S.; Murphy, J.D. What type of digester configurations should be employed to produce biomethane from grass silage? Renew. Sustain. Energy Rev. 2010, 14, 1558-1568. [CrossRef]

66. Ghimire, P.C. SNV supported domestic biogas programmes in Asia and Africa. Renew. Energy 2013, 49, 90-94. [CrossRef]

67. Lansing, S.; Maile-Moskowitz, A.; Eaton, A. Waste treatment and energy production from small-scale wastewater digesters. Bioresour. Technol. 2017, 245, 801-809. [CrossRef] [PubMed]

68. Buysman, E.; Mol, A.P.J. Market-based biogas sector development in least developed countries-The case of Cambodia. Energy Policy 2013, 63, 44-51. [CrossRef]

69. Mao, C.; Feng, Y.; Wang, X.; Ren, G. Review on research achievements of biogas from anaerobic digestion. Renew. Sustain. Energy Rev. 2015, 45, 540-555. [CrossRef] 
70. Lou, X.F.; Nair, J.; Ho, G. Energy for Sustainable Development Field performance of small scale anaerobic digesters treating food waste. Energy Sustain. Dev. 2012, 16, 509-514. [CrossRef]

71. Ferrer, I.; Garfí, M.; Uggetti, E.; Ferrer-Martí, L.; Calderon, A.; Velo, E. Biogas production in low-cost household digesters at the Peruvian Andes. Biomass Bioenergy 2011, 35, 1668-1674. [CrossRef]

72. Martí-Herrero, J.; Chipana, M.; Cuevas, C.; Paco, G.; Serrano, V.; Zymla, B.; Heising, K.; Sologuren, J.; Gamarra, A. Low cost tubular digesters as appropriate technology for widespread application: Results and lessons learned from Bolivia. Renew. Energy 2014, 71, 156-165. [CrossRef]

73. Marchaim, U. Biogas Processes for Sustainable Development; MIGAL Galilee Technological Center: Kirtat Shmona, Israel; FAO: Rome, Italy, 1996.

74. BUILD-A-BIOGAS-PLANT Natural and Renewable. Available online: http:/ /www.build-a-biogas-plant. com/methane-and-biogas / (accessed on 16 November 2017).

75. Bates, L. Biogas. Prat. Action-Technol. Challenging Poverty, Rugby, UK, 2007, 44.

76. Lansing, S.; Bowen, H.; Gregoire, K.; Klavon, K.; Moss, A.; Eaton, A.; Lai, Y.J.; Iwata, K. Methane production for sanitation improvement in Haiti. Biomass Bioenergy 2016, 91, 288-295. [CrossRef]

77. Fixed-dome Biogas Plants. Available online: https://energypedia.info/wiki/Fixed-dome_Biogas_Plants (accessed on 11 October 2017).

78. Ramesh, S.; Usman, A.; Usman, A.; Divakar, B.P. Municipal solid waste management in Bangalore and the concept of mini biogas plant in urban localities. In Proceedings of the 2013 IEEE Global Humanitarian Technology Conference (GHTC), San Jose, CA, USA, 20-23 October 2013; pp. 468-473. [CrossRef]

79. Munasinghe; Sanjeevani Using a biogas. Pratical Action, Rugby, UK, 2003, 44.

80. Karki, A.B. Biogas as renewable energy from organic waste. In BIOTECHNOLOGY; Doelle, H.R., Rokem, S., Beruvic, M., Eds.; Eolss: Oxford, UK, 2009; Volume X.

81. Regattieri, A.; Piana, F.; Bortolini, M.; Gamberi, M.; Ferrari, E. Innovative portable solar cooker using the packaging waste of humanitarian supplies. Renew. Sustain. Energy Rev. 2016, 57, 319-326. [CrossRef]

82. Charlottenburg, A. Rosenheim, Anaerobic Digestion. H; European Bioplastics e.V.: Berlin, Germany, $2015 ;$ p. 8.

83. Itodo, I.; Agyo, G.; Yusuf, P. Performance evaluation of a biogas stove for cooking in Nigeria. J. Energy S. Afr. $2007,18,5$.

84. Martí-Herrero, J.; Ceron, M.; Garcia, R.; Pracejus, L.; Alvarez, R.; Cipriano, X. The influence of users' behavior on biogas production from low cost tubular digesters: A technical and socio-cultural field analysis. Energy Sustain. Dev. 2015, 27, 73-83. [CrossRef]

85. Haque, M.S.; Haque, M.N. Studies on the Effect of Urine on Biogas Production. Bangladesh J. Sci. Ind. Res. 2006, 41, 23-32. [CrossRef]

86. American Public Health Association. Standard methods for Examination of Water and Waste Water; American Public Health Association: Washington, DC, USA, 2005.

87. Halley, P.; Averous, L. Starch Polymers from Genetic Engineering to Green Applications; Halley, P., Averous, L., Eds.; Elsevier: Amsterdam, The Netherlands, 2014; ISBN 9780444537300.

88. Alvarez, R.; Villca, S.; Lidén, G. Biogas production from llama and cow manure at high altitude. Biomass Bioenergy 2006, 30, 66-75. [CrossRef]

89. Mukumba, P.; Makaka, G.; Mamphweli, S. Batch anaerobic co-digestion of cow dung and donkey manure. S. Afr. J. Sci. 2016, 112, 4. [CrossRef]

90. Cummings, J.H.; Bingham, S.A.; Heaton, K.W.; Eastwood, M.A. Fecal weight, colon cancer risk, and dietary intake of nonstarch polysaccharides (dietary fiber). Gastroenterology 1992, 103, 1783-1789. [CrossRef]

(C) 2018 by the authors. Licensee MDPI, Basel, Switzerland. This article is an open access article distributed under the terms and conditions of the Creative Commons Attribution (CC BY) license (http://creativecommons.org/licenses/by/4.0/). 